\title{
A Perspective on Recurrent Vertigo
}

\author{
Richard R. Gacek \\ Department of Otolaryngology, Head and Neck Surgery, University of Massachusetts \\ Medical School, Worcester, Mass., USA
}

\section{Key Words}

Vertigo $\cdot$ Viral etiology $\cdot$ Positional vertigo

\begin{abstract}
The recurrent nature of the 3 most common vestibulopathies suggests a recurrent cause. Histopathology in temporal bones from patients with these syndromes - vestibular neuronitis $(\mathrm{VN}, \mathrm{n}=7)$, Ménière's disease ( $\mathrm{MD}, \mathrm{n}=8$ ) and benign paroxysmal positional vertigo (BPPV, $\mathrm{n}=5$ ) - shows focal degeneration of vestibular nerve axons and degenerated nearby facial nerve meatal ganglion cells. Transmission electron microscopic confirmation of intracytoplasmic viral particles in surgically excised vestibular nerves from patients with VN and MD support a viral etiology in these vestibulopathies. Antiviral treatment of these syndromes in a series of 211 patients with a 3- to 8-year follow-up resulted in complete control of vertigo in VN (88\%), MD (90\%) and BPPV (60\%).

Copyright $(2013$ S. Karger AG, Basel
\end{abstract}

\section{Introduction}

Recurrent vertigo represents a significant disability with serious economic and social implications [1]. The incidence of patients with vertigo seen annually in the USA is 7 million and increasing [2]. Approximately one third of the US population has experienced vertigo by the age 65 years [3]. Although some of these are solitary events, most are recurrent. Since most of these patients lack additional neurological deficits and have negative MRI imaging of the head, the cause is assumed to be located in the inner ear.

Since neurology and otology are the specialties most often consulted to evaluate and treat patients with recurrent vertigo, an update on the pathophysiology and treatment of this disabling symptom is timely [4-6]. The most common vestibular syndromes seen in clinical practice are vestibular neuronitis (VN), Ménière's disease (MD) and benign paroxysmal positional vertigo (BPPV). The official definitions of these syndromes are indicated below. 
Gacek: A Perspective on Recurrent Vertigo

\section{Definitions}

Vestibular Neuronitis

There are two forms of VN: (1) solitary episode of severe vertigo lasting 1 to several days without hearing loss and with no recurrence of vertigo and (2) history of recurrent vertigo (10-15 min to longer than $1 \mathrm{~h}$ ) without hearing loss. Vestibular function may be normal or decreased. Tinnitus and aural fullness may be present in one or both ears. The symptoms of some of these patients may be indistinguishable from those called 'vestibular migraine'. However, there has been no pathological correlation described to support this clinical syndrome.

\section{Ménière's Disease}

MD patients have a history of recurrent vertigo (duration 0.5 to several hours) usually associated with a low-frequency or flat sensorineural hearing loss in one or both ears. Occasionally the hearing loss can be high frequency at the onset, becoming flat with progression. Tinnitus and aural fullness usually present in the affected ear. Vestibular function may be normal or decreased.

\section{Benign Paroxysmal Positional Vertigo}

BPPV patients usually have a sudden onset of a brief rotatory vertigo and nystagmus (duration 15-20 s) after a latency of 1-5 s following positioning the head back or to one side. Subjective and objective signs are greatly reduced or absent when the provocative position is repeated. Hearing and balance function tests are usually normal.

While VN has been commonly regarded as an inflammatory neuropathy [4, 7-9], MD and BPPV are thought to be vastly different pathological entities. MD has been regarded as a disturbance in endolymph homeostasis producing endolymphatic hydrops [10-13]. This has given rise to medical and surgical treatments aimed at reducing the volume of endolymph in the responsible ear. The pathophysiology responsible for BPPV has been assumed to be dislodged gravity-sensitive otoconia from an otolith receptor in the labyrinth which can transform a semicircular canal receptor (usually the posterior) into a gravity-sensitive sense organ $[14,15]$. However, normal adult [16] and pediatric [17] temporal bones (TB) show similar free-floating and cupular fixed deposits in the vestibular labyrinth. Many TB from patients with BPPV do not show otoconial debris in the endolymph [18], and Parnes [15] has reported particles in only one third of patients with severe BPPV who did not respond to repositioning maneuvers. Nevertheless, on this basis repositioning of the loose otoconia by physical maneuvers has gained popular support as conservative management of symptoms. As well the conservative measures used to relieve vertigo in MD [19] and BPPV [20-22] have yielded equivocal results when evaluated in controlled studies. Only ablation of the responsible sense organ has yielded a significant level of relief $[15,23]$.

Therefore, the pathological mechanism in these common vestibulopathies needs reconsideration. Certain features are shared by VN, MD and BPPV.

(1) They commence frequently in adults as a spontaneous event, occasionally as a result of head trauma $[4,7]$.

(2) They typically undergo spontaneous remission and become recurrent [4].

(3) They usually involve one ear with a 15-20\% incidence of bilaterality [24].

(4) They may coexist in the same ear, i.e. VN + BPPV or MD + BPPV [25].

(5) There is a significant loss of vestibular neurons and degenerated facial nerve sensory ganglion cells in all 3 vestibulopathies [8, 9, 26-28].

(6) There is a tendency for these syndromes to affect other members of the same family [29]. 
(7) They frequently follow a period of extreme physical or nonphysical stress in the patient's life [30].

The many shared features of these 3 syndromes support the concept of a common etiology. The incidence of elevated HSV-I antibody levels (60\% in the population worldwide by the age of 25 and $90 \%$ by the age of 60 ) raises the question of a role of neurotropic (NT) viruses (alpha herpes virinae subfamily) in these vestibulopathies [31]. This group of viruses has a propensity for invading sensory neurons, establishing latency within the nucleus of the ganglion cell, and becoming reactivated at a later (years) date during a period of extreme stress $[32,33]$. The best known members of this group of viruses are herpes simplex HSV types 1 and 2, and Herpes zoster (varicella) virus [34]. Other members of this family of NT viruses are cytomegalo-inclusion virus, pseudorabies and Epstein-Barr virus.

Since there is such wide exposure to these NT viruses, it seems remarkable that only a small portion of the population develops recurrent vertigo. Even more striking is the fact that several members of a family may develop these recurrent disorders. It has been postulated that inheritance may play a role in the familial occurrence of MD or VN. An alternate explanation however, is the importance of negatively charged heparan sulfate receptors in the plasma membrane of sensory neuron terminals. These receptors are required for positively charged glycoproteins in the virus envelope to combine with in order to enter the axoplasm for transport to the nucleus where permanent residence takes place. The presence of these receptors is determined genetically.

Within these major types are hundreds of strains representing differing degrees of virulence and resistance as well as mutancy. The wide variety in this family of NT viruses and the different functional groups of ganglion cells in the vestibular nerve which can be selectively altered by virus means that there may be a wide variety of clinical vestibular syndromes encountered in the patient with recurrent vertigo. Terms such as 'recurrent vestibulopathy', 'acute neurolabyrinthitis', 'psychogenic vestibulopathy' and 'cochlear MD' may have arisen because of features and findings in patients who do not conform to the official definitions of VN, MD or BPPV.

Other studies have demonstrated the presence of HSV antibodies or DNA [35, 36] in vestibular nerves and nuclei from patients with VN and MD and in the perilymph of patients with MD [37]. Furthermore, MRI imaging has demonstrated enhanced vestibular nerve ganglia in patients with VN [38] and MD [26], suggesting an inflammatory process in the vestibular nerve [39]. The chemicals elevated in the stress response (cortisol and adrenalin) are capable of allowing the virus to reactivate [40] and cause symptoms by destroying groups (clusters) of ganglion cells. Reactivation of latent HSV-1 has been confirmed in animalcultured (rat) vestibular ganglion cells [34]. A major deterrent to the acceptance of a viral neuropathy in these common vestibular syndromes is the lack of history pointing to a recognizable viral insult to the ear. However, the mucous membrane of the aero digestive tract is a ready portal of entry for NT viruses to invade sensory terminals of cranial nerves (olfactory, trigeminal, facial, vagus and glossopharyngeal). The facial nerve has a unique location adjacent to the vestibular nerve and ganglion in the internal auditory canal.

A neuropathy causing facial nerve dysfunction (Bell's palsy) is thought to be caused by virus reactivation in the sensory ganglia of this nerve (fig. 1). The human facial nerve has 2 sensory ganglia, geniculate and meatal $[41,42]$. Although the geniculate ganglion represents the major sensory input (80-85\%) in most facial nerves, the meatal ganglion is present in all specimens and may outnumber the geniculate in $10-15 \%$ of TB.

Four TB from patients with a history of facial paralysis (Bell's palsy) demonstrated only degenerated meatal ganglion cells and no degeneration in the geniculate [43]. Several MRI studies of patients with Bell's palsy show that the earliest enhancement of the facial nerve is in the fundus of the internal auditory canal where the meatal ganglion is located [43]. 
Gacek: A Perspective on Recurrent Vertigo

Fig. 1. Photomicrograph demonstrating the proximity of the meatal ganglion to the vestibular ganglion. $\mathrm{M}=$ Meatal ganglion; $\mathrm{V}=$ vestibular ganglion; $\mathrm{F}$ = facial nerve.

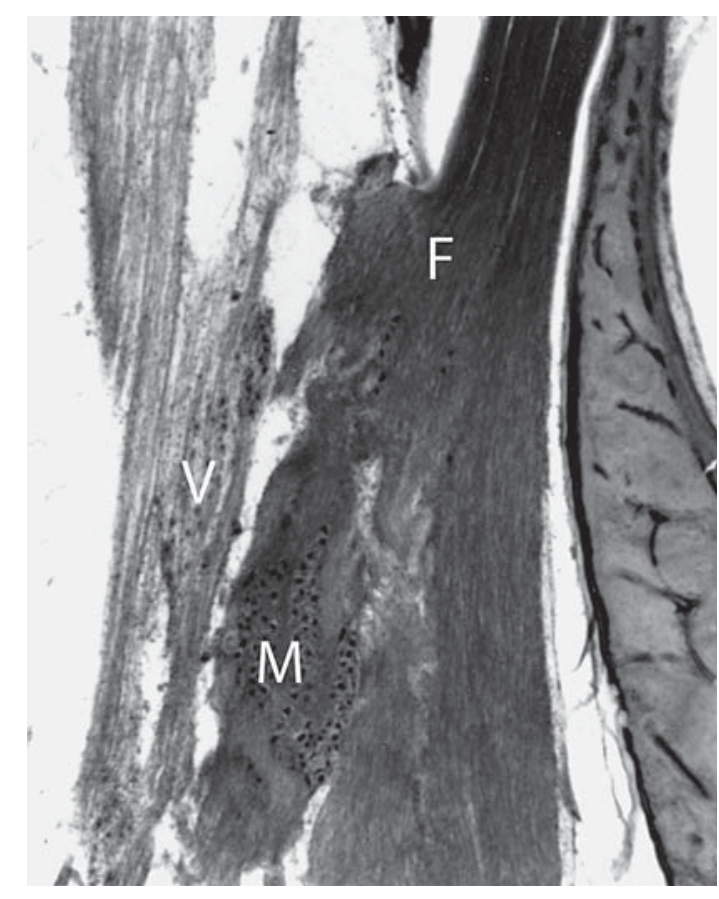

Fig. 2. Drawing of the neural pathway for protein transport from the soft palate to the meatal ganglion and the vestibular ganglion.

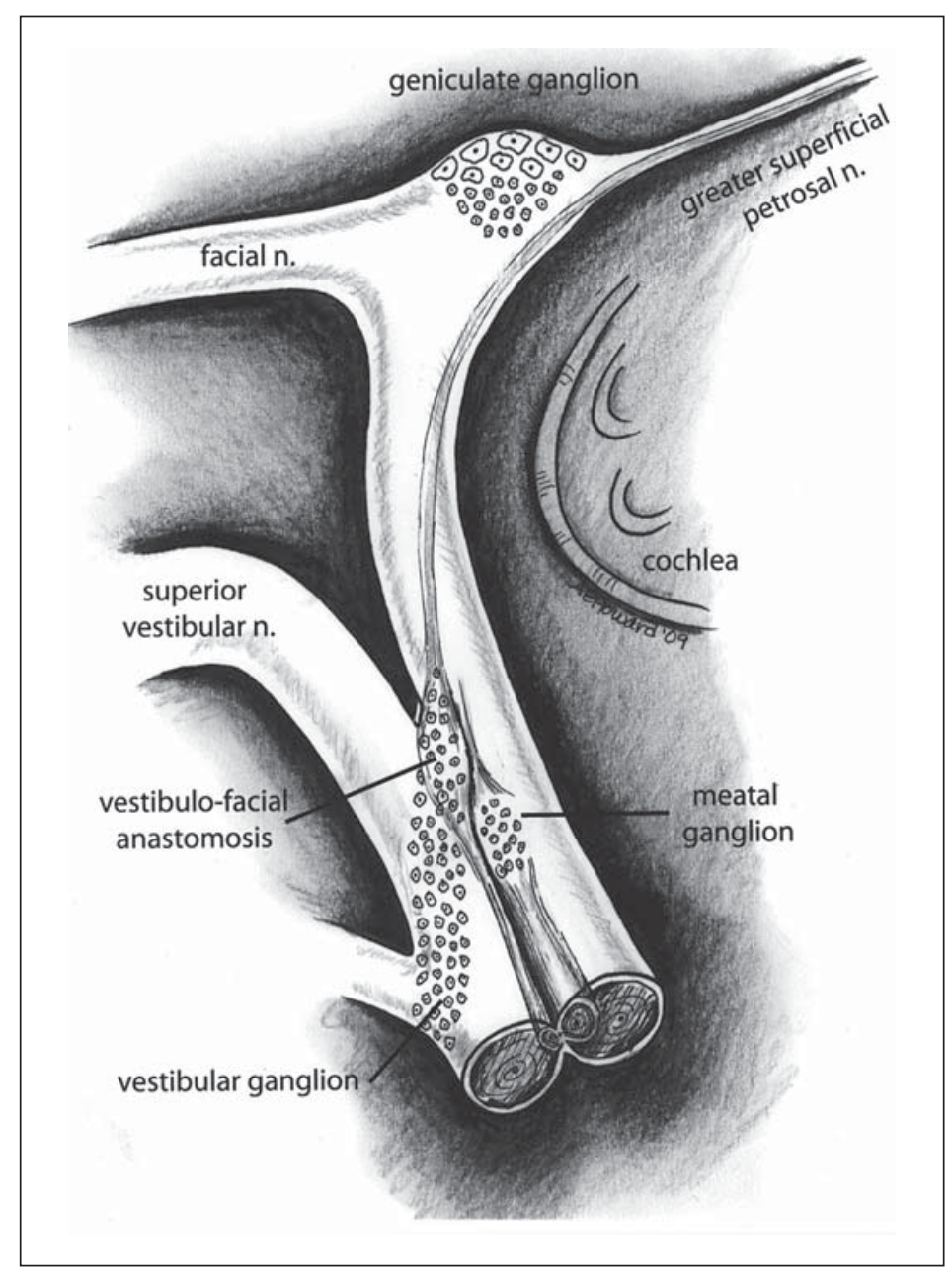




\begin{tabular}{l|l}
\hline ORL $2013 ; 75: 91-107$ & $\begin{array}{l}\text { @ } 2013 \text { S. Karger AG, Basel } \\
\text { www.karger.com/orl }\end{array}$ \\
\hline DOI: $\underline{10.1159 / 000348710}$ &
\end{tabular}

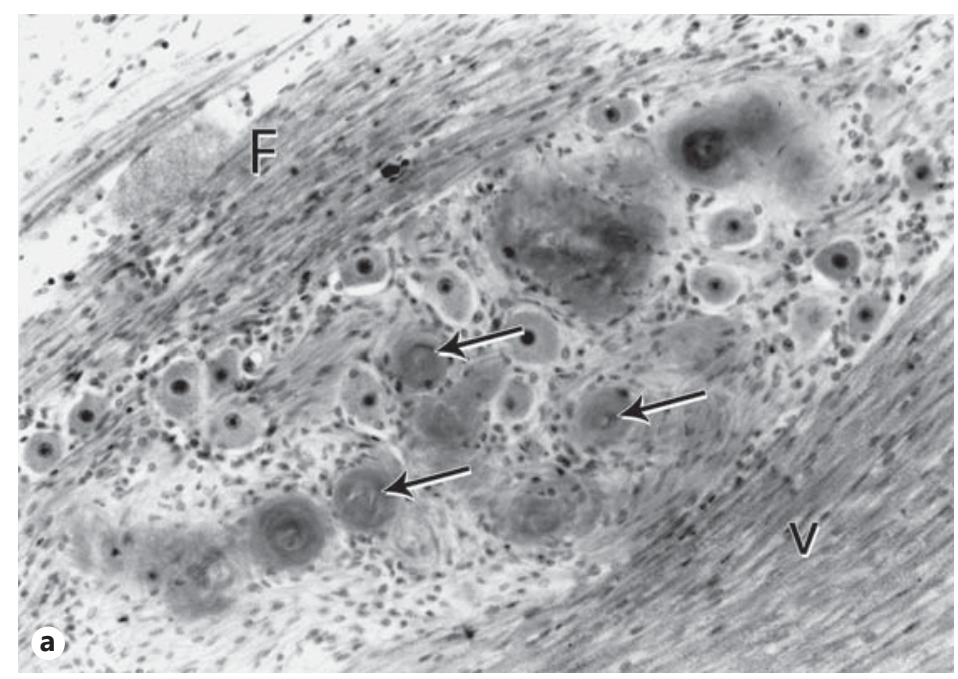

Fig. 3. a Degenerated meatal ganglion cells (arrows) in a case of VN. Magnification $\times 280 . F=$ Facial nerve; $\mathrm{V}=$ vestibular ganglion. b Higher power photomicrograph demonstrates the encirclement and deposition of collagen in meatal ganglion cells by satellite cells (arrowheads). Magnification $\times 450$.

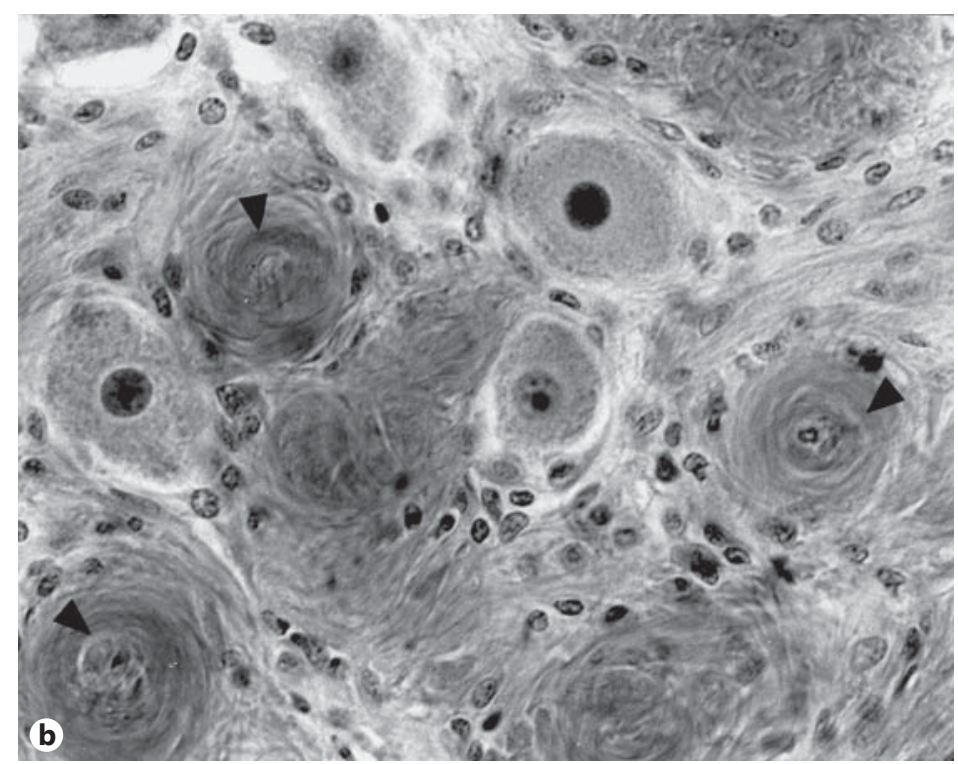

Furthermore, a recent study has demonstrated that the input to the meatal ganglion is from receptors in the palate via the greater superficial petrosal nerve [44]. The input to the geniculate ganglion is from taste receptors in the anterior tongue. The meatal ganglion is adjacent to the vestibular ganglion and some of its neurons are located within the vestibular ganglion (fig. 2). Therefore, a pathway from the palate to the vestibular ganglion exists for the transport of foreign proteins (viral) during life.

\section{Pathology of VN, MD and BPPV}

The TB from patients with VN, MD and BPPV $[45,46]$ show similar pathology in the facial and vestibular nerves. Degenerated ganglion cells in the meatal ganglion (fig. 3) and fascicles of degenerated axons in the vestibular nerve (fig. 4) were seen in TB for patients with documented histories of $\mathrm{VN}(\mathrm{n}=7)$ [26]. The initial localization of virus is in the meatal ganglion 


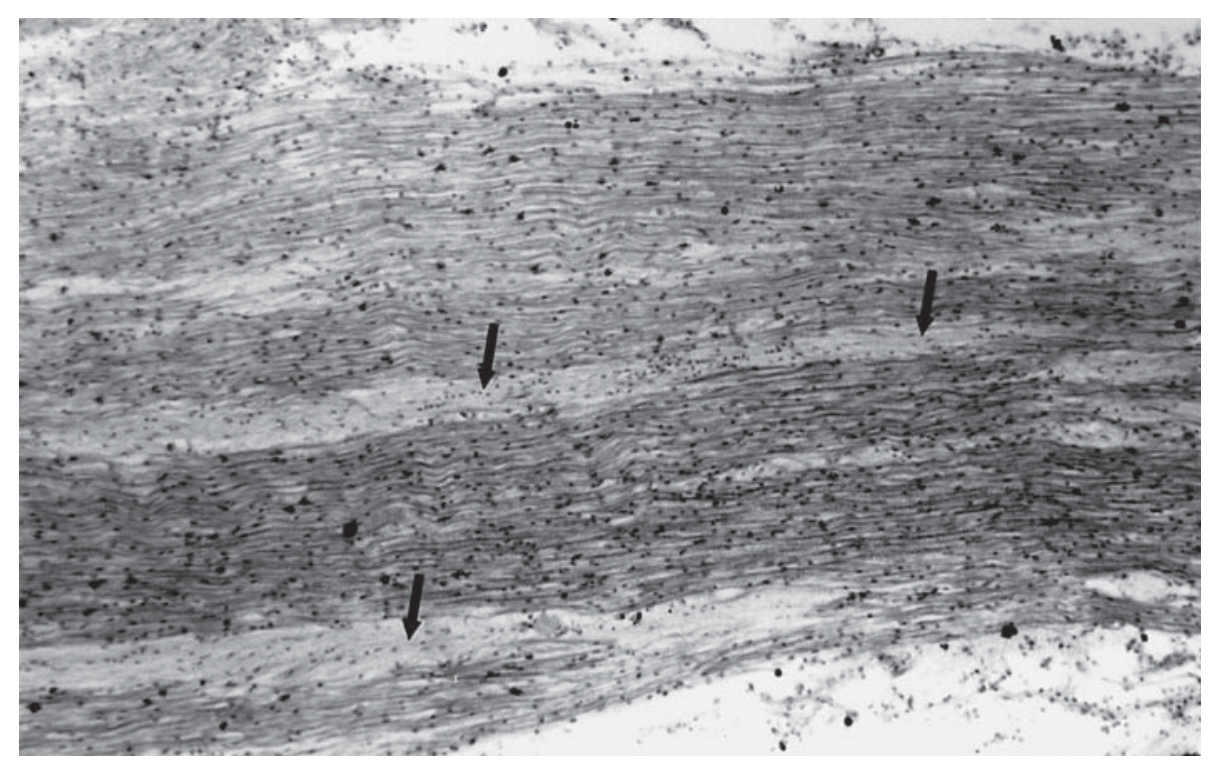

Fig. 4. Lower power view of bundles of degenerated axons (arrows) in the left vestibular nerve trunk of the patient in figure 3. He was a 71-year-old male with prostate cancer admitted to hospital for severe vertigo and nausea. He had bilateral high-frequency sensorineural hearing loss with slightly reduced word discrimination and a diminished caloric response on the left. Magnification $\times 64$.

but over time there is cell-to-cell spread to ganglion cells in the superior vestibular division. Similar findings of degenerated ganglion cells in the meatal ganglion and focal axonal degeneration in the vestibular nerve were observed in $\operatorname{MD}(n=8)[27,47,48]$ (fig. 5, 6). The presence of degenerated axons as compact similar-sized fascicles in the vestibular nerve trunk can only be explained by a loss of closely arranged clusters of ganglion cells.

Such clusters of affected ganglion cells both in the meatal and vestibular ganglion are the result of cell-to-cell spread of virus over time. When the viral load reaches a critical level in enough neurons the virus is reactivated and breaks through the ganglion cell plasma membrane causing degeneration. Reports of demyelination in vestibular nerve axons excised to relieve symptoms of refractory unilateral MD support the observations in the present study [70]. Reactive supporting cells indicated that microglia assumed a phagocytic role in this degenerative process. A comparison of these vestibulopathies and an age- and sex-matched series of TB did not reveal degenerated cells in the meatal ganglion or focal vestibular axonal degeneration in the control series [45]. This rules against these changes being due to aging.

A significant difference between the histopathology in VN and MD is fibrous tissue stretching between the utricular nerve and the stapes footplate in MD (fig. 7), while the vestibular cistern in VN is free of fibrosis. This fibrosis, thought to be responsible for Hennebert's sign in MD [48], has been observed in 40\% of TB from MD patients [13]. The fibrous tissue response in MD may be responsible for endolymphatic hydrops [49, 50] (fig. 8). Since this inflammatory insult represents a serofibrinous labyrinthitis, it is probably caused by toxic nucleic acids released from utricular nerve endings into the perilymph of the scala vestibuli [51]. Ultimately these toxins enter the apical turn scala tympani where they produce damage to the hair cells in the organ of Corti and cochlear nerve resulting in a low-frequency hearing loss (fig. 9). 


\begin{tabular}{l|l}
\hline ORL 2013;75:91-107 \\
\hline DOI: $\underline{10.1159 / 000348710}$ & $\begin{array}{l}\text { @ 2013 S. Karger AG, Basel } \\
\text { www.karger.com/orl }\end{array}$ \\
\hline
\end{tabular}

Fig. 5. Degenerated meatal ganglion cells (arrows) in a case of MD. F = Facial nerve; $\mathrm{V}=$ vestibular nerve. Magnification $\times 280$.

Fig. 6. The vestibular nerve in this patient with MD: a 76-year-old woman with bilateral severe flat sensorineural hearing loss and recurrent episodes of vertigo lasting for hours. There are numerous bundles of degenerated axons in the nerve trunk (arrows). Magnification $\times 64$.

Fig. 7. There was fibrous tissue (asterisk) stretching from the under surface of the utricular nerve into the vestibular cistern. $\mathrm{U}=$ Utricular nerve. Magnification $\times 80$.
Gacek: A Perspective on Recurrent Vertigo
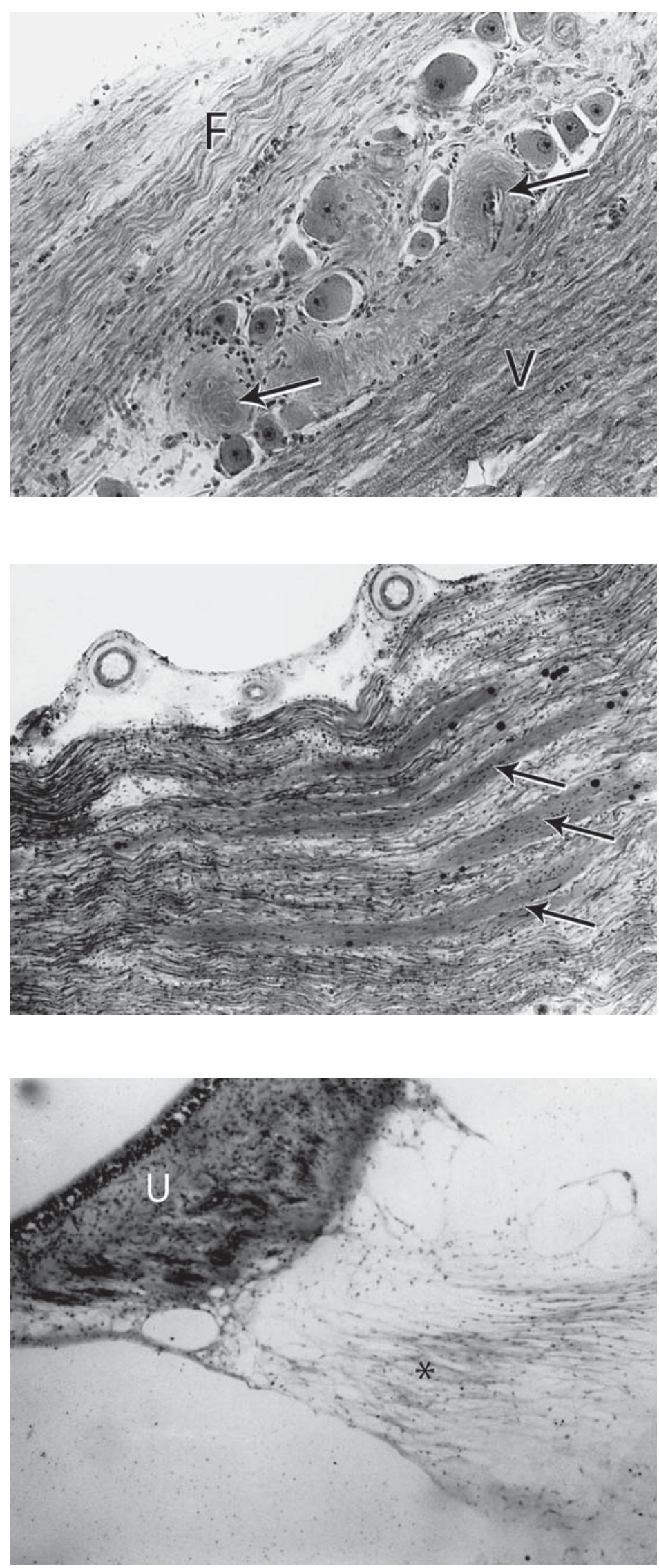
Fig. 8. Fibrous tissue (asterisk) filled the perilymphatic space under the stapes footplate and surrounded a dilated saccule. $\mathrm{FP}=$ Stapes footplate; $\mathrm{S}=$ saccule. Magnification $\times 80$.

Fig. 9. Schema of the flow of viral nucleic acids in MD. Release of toxic end products from the utricular nerve causes a serous/fibrous labyrinthitis and hydrops. Further flow up the scala vestibuli reaches the scala tympani of the apical turn of cochlea where a toxic effect on hair cells and spiral ganglion causes low-frequency hearing loss. U = Utricular nerve; $\mathrm{S}=$ saccule; $\mathrm{VG}$ = vestibular ganglion; RW = round window.
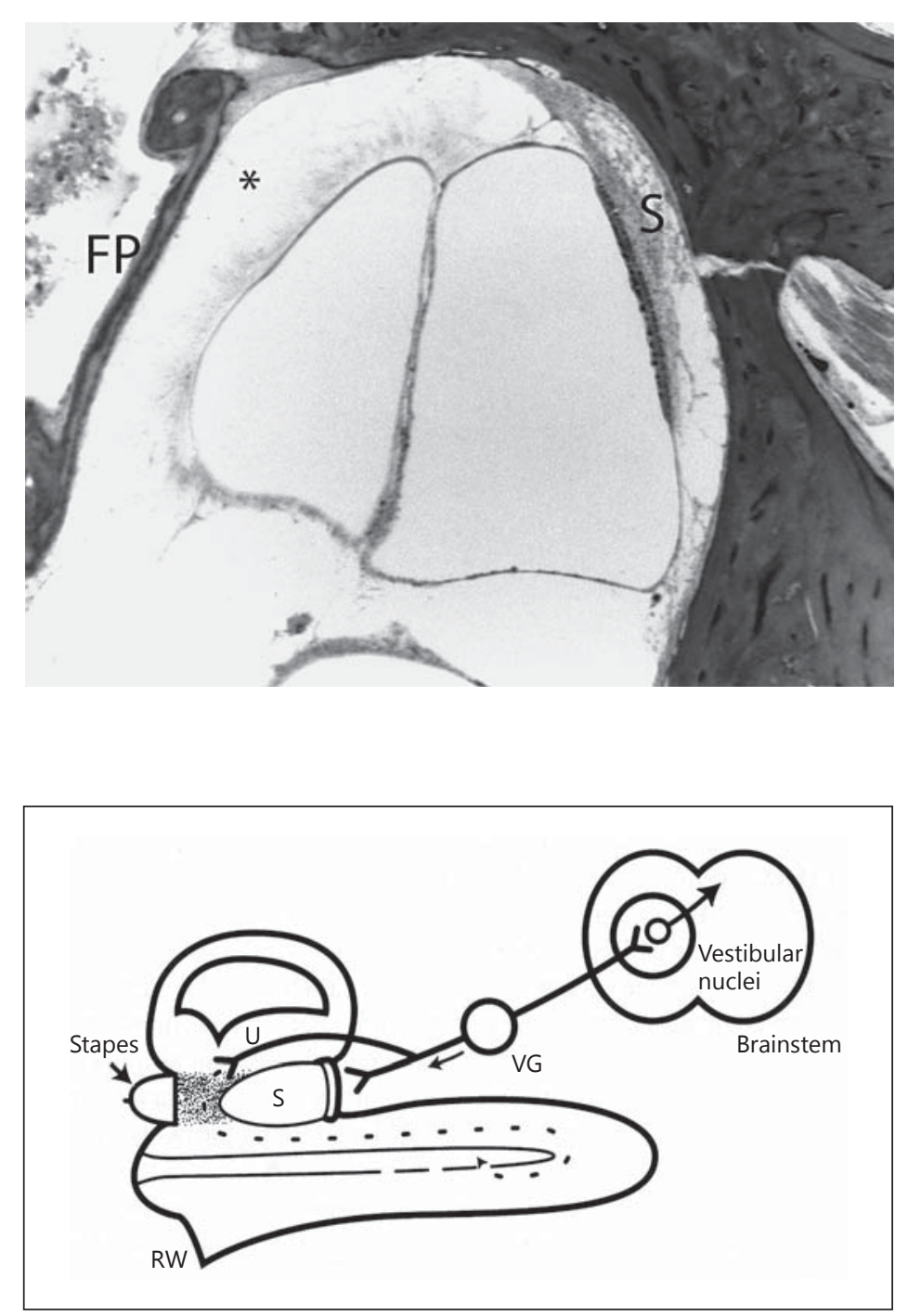

Since the disruption of the cytoplasmic membrane in vestibular ganglion cells creates a drastic change in the ionic gradient across the membrane, vertigo is produced, depending on how many cells are affected. In MD the severity of the vertigo is greater than in VN because, in addition to the vestibular neurons directly affected by virus activation, there is a chemical labyrinthitis caused by the release of viral nucleic acids into the perilymph. This labyrinthine disturbance also affects intact neurons in the affected vestibular nerve.

The sensorineural hearing loss in MD typically presents as low-frequency or flat-threshold elevation. The spread of viral toxic byproducts in the perilymph of the scala vestibuli must reach the apical scala tympani where they have the opportunity to enter Rosenthal's canal and the organ of Corti through perforating channels in the osseous spiral lamina.

Depending on the duration and severity of this toxicity the hearing loss may be reversible. In our experience $30 \%$ of MD patients may have improvement in hearing following antiviral therapy. Such an improvement in hearing has been reported following middle fossa excision of the vestibular ganglion, which represents removal of virus-containing neurons [22].

The presence of degenerated axons as compact similar-sized fascicles in the vestibular nerve trunk can only be explained by a loss of closely arranged clusters of ganglion cells. 
Fig. 10. Schema of the anterograde flow of viral nucleic acids following reactivation of virus in the vestibular ganglion in $\mathrm{VN}$. This direction of virus flow avoids hearing loss but may cause virus presence in second-order neurons (for abbreviations, see legend of fig. 9).

Fig. 11. Photomicrograph from the TB of a patient with delayed endolymphatic hydrops (MD) shows many dark and cystic structures (arrowheads) stretching from the utricular nerve into the vestibular cistern. $U$ = Utricular nerve. Dark cells marked by an arrow are shown with high power in figure 12 . Magnification $\times 80$.
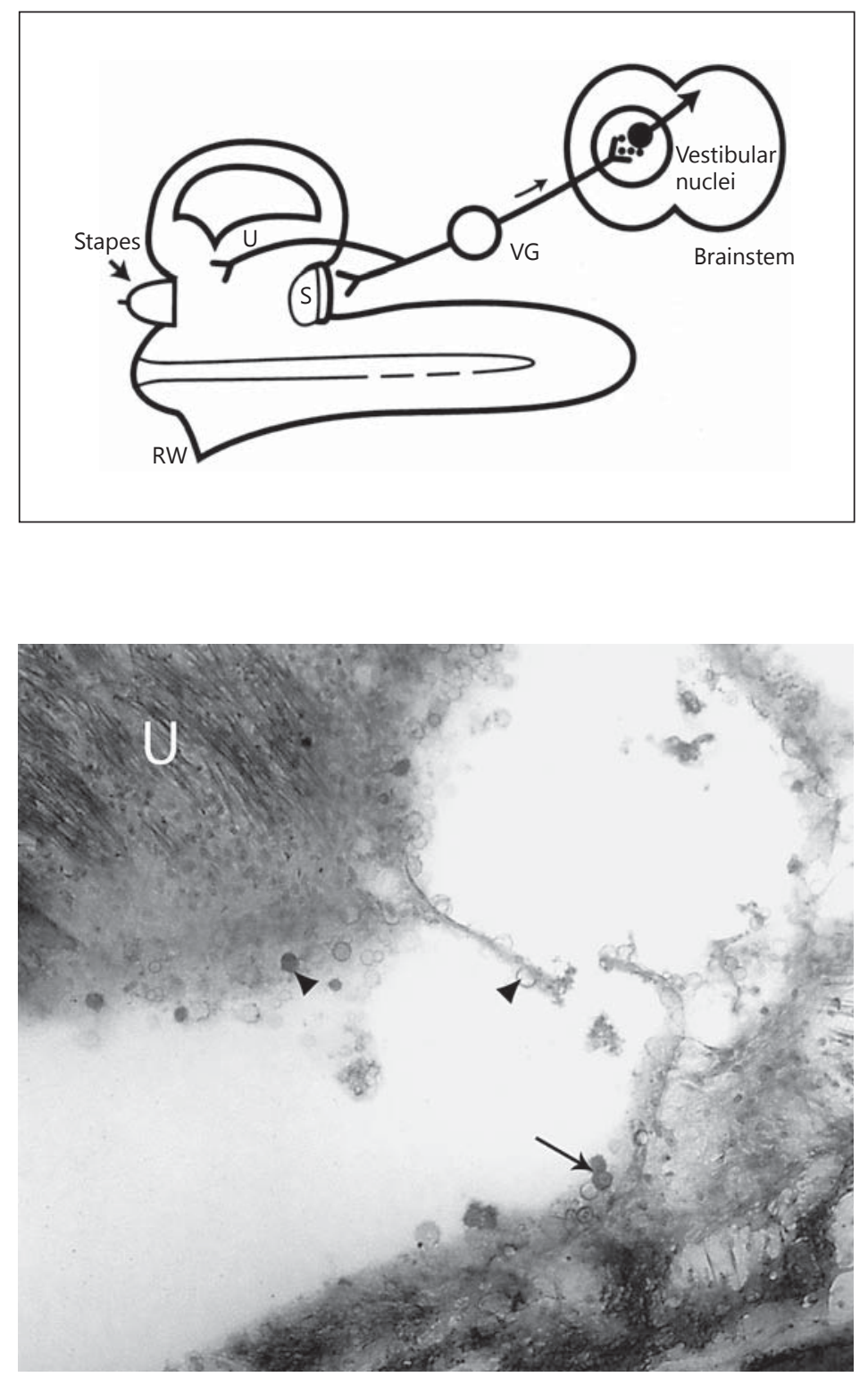

The different vestibular syndromes (VN and MD) which result from reactivation of the NT virus in the superior vestibular ganglion may depend on the strain and load of the virus [52-54]. If the intra-axonal virus flow is toward the brainstem, as with the H125 strain of HSV-I, VN will be the clinical presentation (fig. 10). Transsynaptic transmission of the virus to second-order neurons in the vestibular nuclei is possible in VN. The intra-axonal flow of activated virus toward the inner ear such as the McIntyre strain of HSV will give rise to the clinical manifestations of MD (fig. 9).

The release of NT viral toxins from the utricular nerve in MD is illustrated by the inclusion body of the cytomegalovirus which is visible by light microscopy [55].

Figure 11 is a TB photograph from a patient with delayed endolymphatic hydrops, which is a variant of MD $[29,56]$. The intranuclear inclusion body cells and microcysts released from the utricular nerve are diagnostic of the cytomegalovirus [55] (fig. 12). Endolymphatic hydrops was present in the saccule and cochlea (fig. 13). 
Gacek: A Perspective on Recurrent Vertigo

Fig. 12. High-power image of cells in the perilymphatic space demonstrates a large nuclear inclusion surrounded by a halo in the nuclear sap (arrows). Magnification $\times 450$.

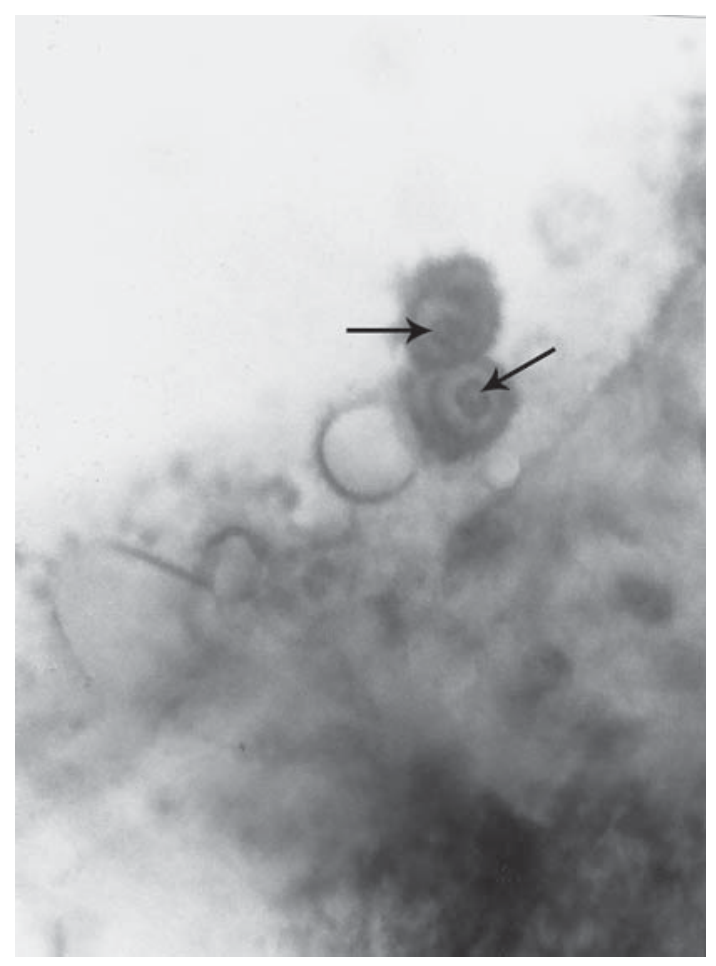

Fig. 13. Dilated saccular wall (arrow) in the same case confirms endolymphatic hydrops. $\mathrm{S}=$ Saccular macula; FP = stapes footplate. Magnification $\times 80$.

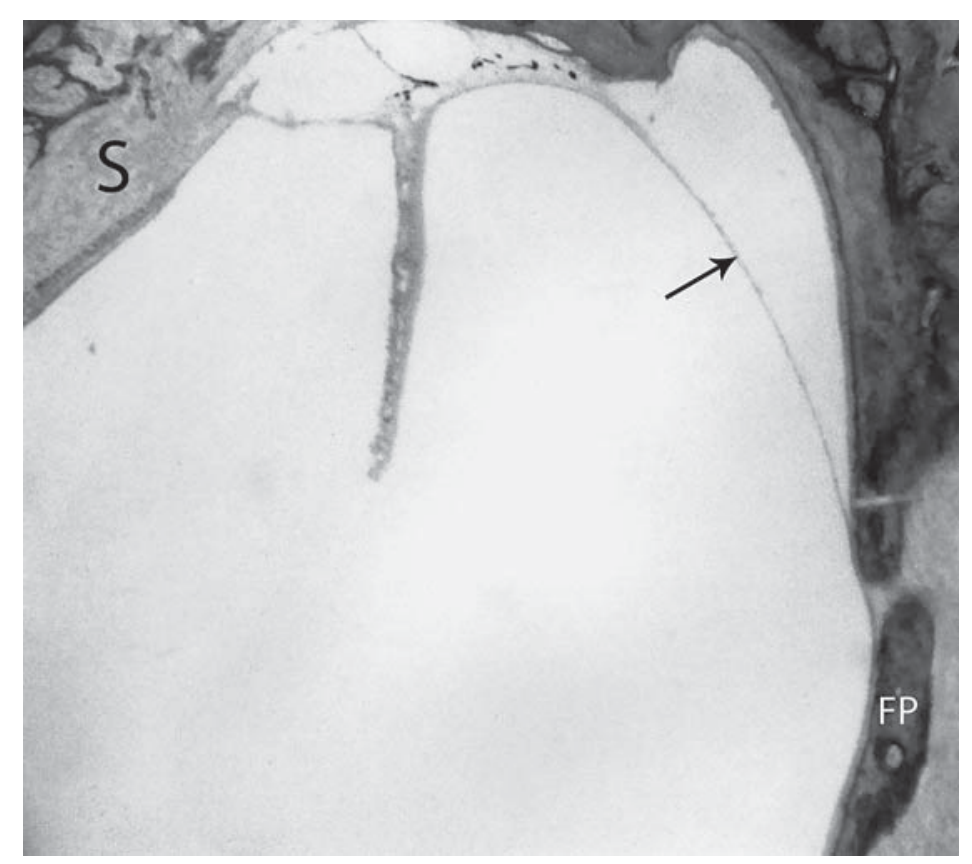

Direct evidence of a viral etiology for both VN and MD is provided by transmission electron microscopy of vestibular nerves excised from patients with these 2 syndromes. Viral particles were found in the cytoplasm of vestibular ganglion cells excised in 1 patient with VN (fig. 14) and in 3 with MD (fig. 15). Since the component protein parts of the virus are found within the nucleus of the ganglion cell during its latent phase, viral structures are not found 
Fig. 14. Vestibular nerve and ganglion excised from a patient with BPPV and VN who lost hearing following posterior canal occlusion. Viral particles (arrows) enclosed in transport vesicles were found in cytoplasm of ganglion cells. Magnification $\times 46,000$.

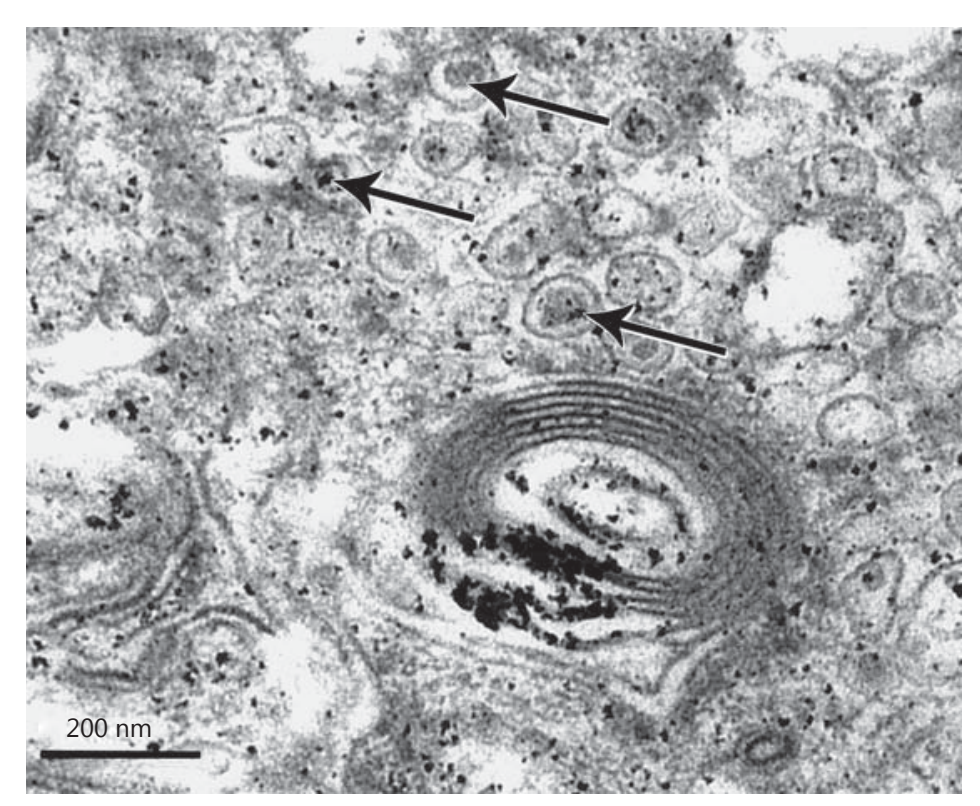

Fig. 15. Electron microscopic

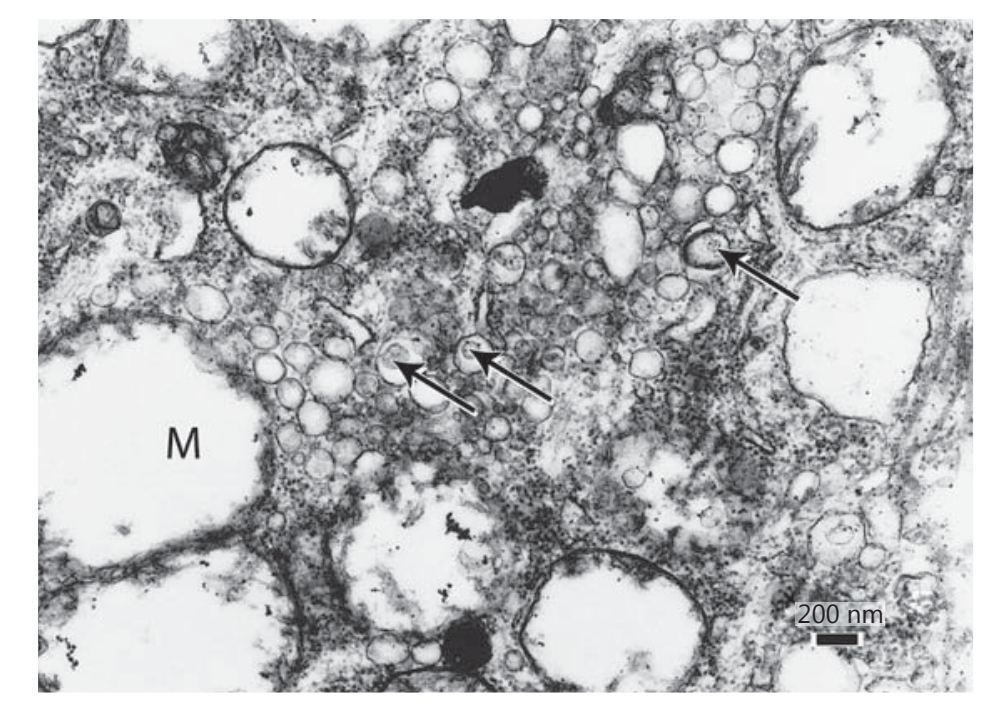
exam of excised vestibular nerve in a patient with MD revealed viral capsids enclosed in transport vesicles (arrows). $\mathrm{M}=$ Mitochondria. This 45-year-old female has been previously reported. Magnification $\times 13,000$.

in the nucleus. However, the complete virus is assembled during the passage through the nuclear membrane into the cytoplasm of the cell [33]. The fully formed virus particles are found enclosed in transport vesicles contained in the cytoplasm of the ganglion cell.

If the reactivated virus is located in the inferior division of the vestibular nerve, it affects the saccular ganglion initially because of its proximity to ganglion and satellite cells containing virus in the larger superior division and the meatal ganglion. Recording cervical muscle potentials (vestibular-evoked myogenic potential) has shown decreased saccular function in patients with posterior canal BPPV $[57,58]$. Since transection of the posterior ampullary nerve relieves BPPV [23], there is a possibility that the interrelationship between the two sense organs is important in BPPV. Degeneration of the saccular ganglion has been documented in two TB of patients with posterior canal BPPV (fig. 16, 17). In this way BPPV can coexist with either VN or MD. It has been established in human as well as experimental animal studies that there is a strong inhibitory influence by otolith organs on the neural input from canal afferents [59-62]. 
Fig. 16. Photo of saccular ganglion cells in the TB from a 75-yearold female with a 10-year history of posterior canal BPPV undergoing degeneration by replacement and collagen disposition from satellite cells (arrows). Intact ganglion cell (arrowhead). Magnification $\times 450$.

Fig. 17. Degeneration of the left saccular nerve (arrow) in a 65year-old male who suffered head trauma followed by posterior canal BPPV for 6 months prior to death from pneumonia. Caloric tests were normal bilaterally but he had a positive Hallpike test. $\mathrm{VG}=$ Vestibular ganglion. Magnification $\times 64$.
Gacek: A Perspective on Recurrent Vertigo
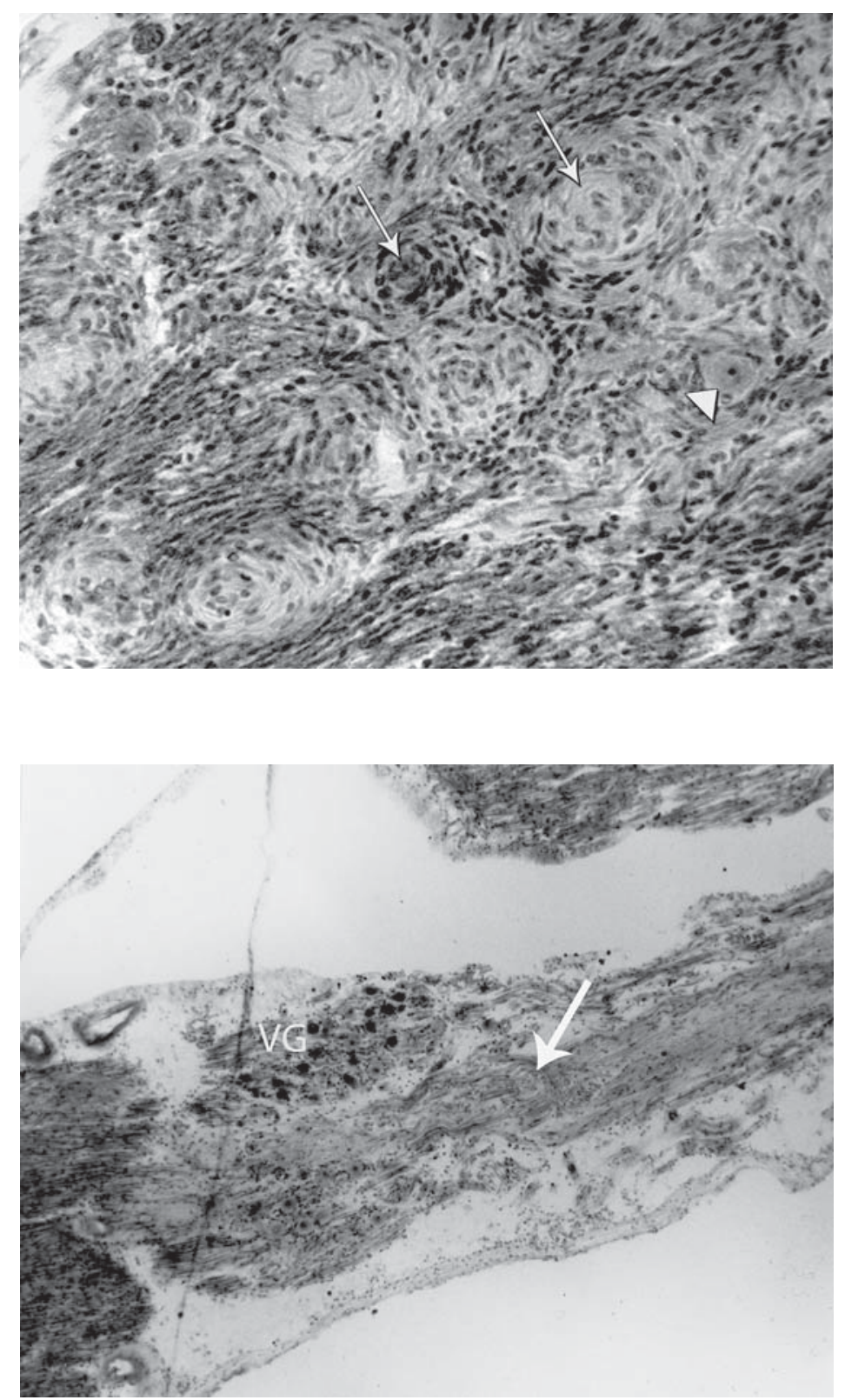

Thus, the inferior half of the saccular macula having hair cell polarization similar to that of the posterior canal crista exerts its inhibitory effect on provoked canal neural activity. In a similar arrangement each half of the utricular macula has a HC polarization aligned with either the lateral or anterior canal crista, allowing for the same otolith-canal interrelationship. Decreased utricular innervation may then present as lateral or superior canal BPPV.

An explanation for the high frequency of posterior canal BPPV may be found in the neural input from these sense organs. It is known that individual vestibular nerve branches are numerically similar [63]. Therefore, each half of the utricular or saccular macula will exert its inhibitory effect over half the number of afferent neurons as those in the ampullary nerve. It has been reported in the TB of patients with BPPV that there is at least $50-70 \%$ loss of vestibular neurons [28]. The impact of such a loss of neurons will more severely limit the smaller input from the otolith receptor than from the canal receptor. 
Fig. 18. Schema of the proposed neural pathways in posterior canal BPPV. The open circle neuron in the medial vestibular nucleus is an inhibitory neuron, while all others are excitatory. PC = Posterior semicircular canal; SAC = saccule; III = oculomotor nucleus; IV = trochlear nucleus; $\mathrm{S}=$ superior vestibular nucleus; $\mathrm{L}=$ lateral vestibular nucleus; $\mathrm{M}=$ medial vestibular nucleus.

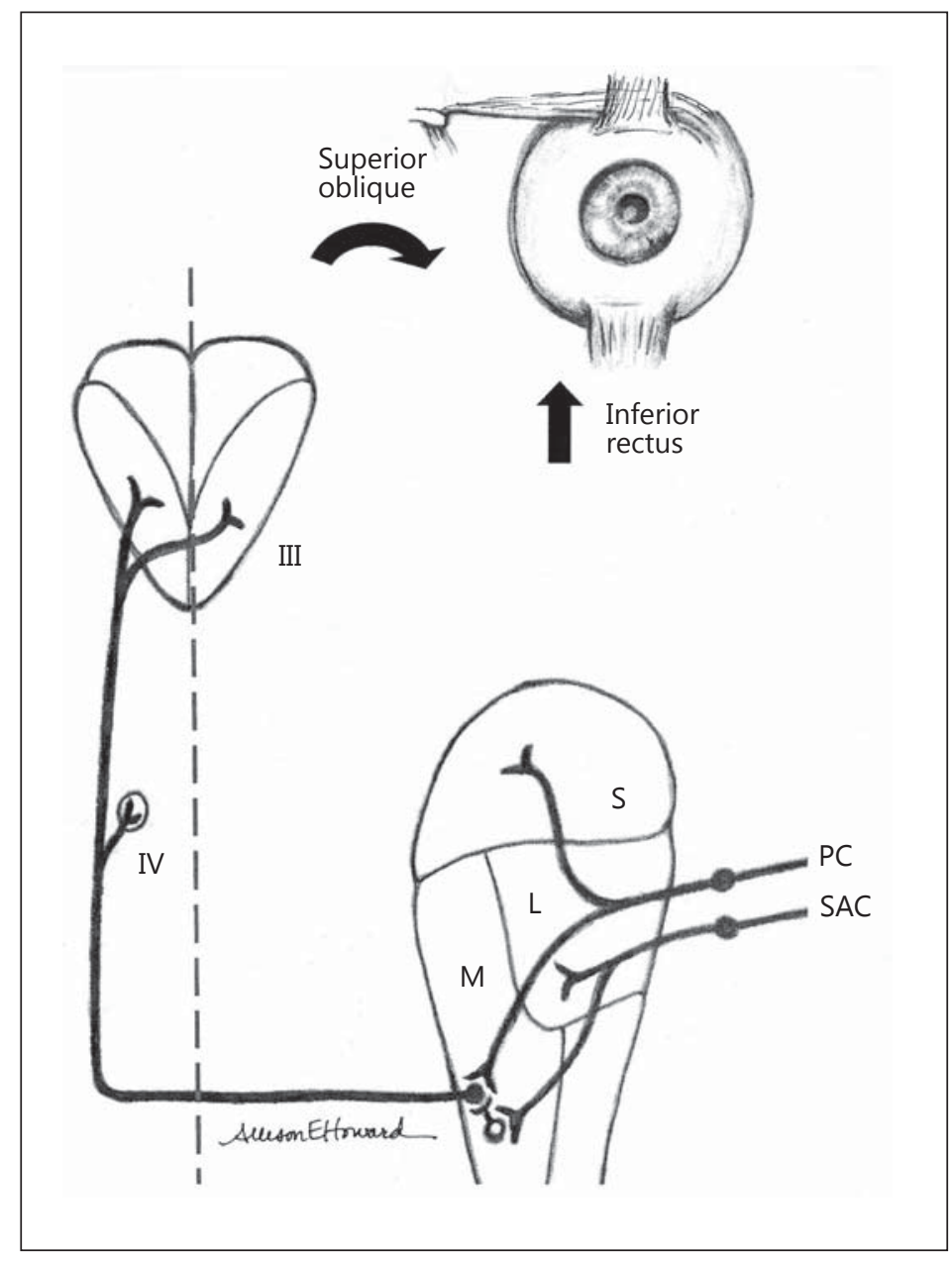

The neural diagram in figure 18 illustrates the neural pathways underlying this relationship between the saccule and the posterior semicircular canal. This interaction occurs in the medial vestibular nucleus as a disynaptic pathway, using commissural neurons to provide the inhibitory effect on the excitatory vestibuloocular pathway from the posterior canal. A similar neural mismatch exists between the utricle and the lateral or superior canal crista, giving rise to BPPV of those canals. Therefore, a neural mechanism rather than loose otoconia is possible in BPPV. The beneficial effects of the repositioning maneuvers are compatible with this neural mechanism of BPPV. Completing the maneuver stimulates all vestibular sense organs. Therefore, otolith afferent neuron excitability reduced by viral replication could be reinforced by the maneuver, resulting in increased inhibition to relieve BPPV. However, complete degeneration of all or nearly all otolith neurons will be responsible for the recurrence of positional vertigo.

\section{Clinical Series}

Since these vestibular syndromes are a manifestation of viral neuropathy, the use of antiviral drugs should provide clinical evidence of the viral cause. A clinical series of patients with a diagnosis of MD, VN or BPPV were treated orally with acyclovir or valacyclovir to relieve 
vertigo not controlled with conservative measures (diuretics, low-salt diet, meclizine and valium). This represents an extension of a series of patients reported earlier [27]. These 211 patients include 140 females and 71 males (aged 23-88 years) who were treated from April 2004 to March 2009. The choice of acyclovir as antiviral medication was based primarily on cost. Valacyclovir (Valtrex) has better bioavailability but is much more expensive and may not be covered by most insurance plans. All of these patients had failed standard medical treatment for recurrent vertigo (meclizine, valium, diuretics and low-salt diet) for periods ranging from 6 months to years. They were considered refractory to the standard treatment of vestibulopathy.

Attempts to construct a control group of patients undergoing antiviral treatment were unsuccessful. Having failed traditional treatments, these patients with significant vertigo were referred because they desperately sought relief. Therefore, these results can be viewed as uncontrolled. However, there is support for a practice-based approach $[64,65]$ to determine the effectiveness of new treatments for disorders of unknown etiology.

The antiviral treatment protocol for patients with recurrent vertigo is as indicated below.

Discontinue all previous medical treatments; ensure that patients are cleared for normal renal and liver function; use acyclovir tabs $800 \mathrm{mg}$ t.i.d. for 3 weeks and reexamine. If there is significant relief of vertigo, decrease to $800 \mathrm{mg}$ b.i.d. for 3 weeks, then to $800 \mathrm{mg}$ daily as a maintenance dose. If valacyclovir is selected (in those who fail to respond to acyclovir), use $1 \mathrm{~g}$ t.i.d. for 3 weeks with taper to b.i.d. for a further 3 weeks and then $1 \mathrm{~g}$ daily as a maintenance dose. The starting dose of acyclovir was given for a longer period ( 3 weeks) than that used for zoster because it was felt necessary to cross the blood-brain barrier to reach ganglion and satellite cells with virus. Most patients experienced relief from vertigo in the first 2 weeks but some required a longer period. The gradual lowering dose was then used to find the lowest level maintenance dose for a given patient. Most were controlled on a single dose daily but occasionally a patient required an adjustment to 1,200 $\mathrm{mg}$ of acyclovir or 1,500 $\mathrm{mg}$ of valacyclovir.

These dosages may require adjustment in patients with impaired kidney or liver function. The follow-up period was as short as 3 years in the most recent patients and 8 years in the earliest patients in the series. Of 106 patients with VN (the earliest patients evaluated up to 8 years), 93 (88\%) had complete relief of symptoms with oral acyclovir, 54 of 60 patients (90\%) with MD were relieved of vertigo, and 27 of 45 patients $(60 \%)$ with posterior canal BPPV were relieved of symptoms. Between the use of antivirals and repositioning maneuvers (physical therapy), the number of chronically disabled patients who were candidates for ablation of posterior semicircular canal function (canal occlusion or singular neurectomy) was reduced significantly.

As a result of these morphological and clinical observations, our approach to the patient with recurrent vertigo has been simplified. It goes without saying that the patient without recurrent balance symptoms needs no further treatment after a hearing test and MRI of the brain (assuming that these are normal). A Hallpike maneuver is included in the initial examination. Those patients with recurrent vertigo are offered a trial of oral acyclovir (or Valtrex) for 3 weeks.

Examination at the 3-week period will determine the sensitivity of the particular NT virus to the antiviral. If there is no relief of vertigo with acyclovir or valacyclovir, treatment is followed by vestibular tests (videonystagmography and vestibular-evoked myogenic potential) to determine the responsible ear. If these results are abnormal chemical labyrinthotomy is offered. The patient is offered a choice between dexamethasone $(12 \mathrm{mg} / \mathrm{ml})$ or gentamycin $(80 \mathrm{mg} / 2 \mathrm{ml})$, considering the risk of hearing loss (dexamethasone $0 \%$; gentamycin usually negligible if used in a single small dose). 
Gacek: A Perspective on Recurrent Vertigo

\section{Summary}

The concept that recurrent vertigo is caused by reactivation of an NT virus (Herpes family) is based on TB changes in the meatal ganglion of the facial nerve as well as in the adjacent vestibular ganglion. These light microscopy observations are supported by transmission electron microscopy, which demonstrated fully formed viral particles in vestibular ganglion cells excised from patients with VN and MD. Treatment with acyclovir has the advantage of preserving the vestibular neural network, allowing compensation of the deficits caused by vestibular ganglion cell degeneration resulting from virus reactivation [66]. Usually this recovery is effective leaving no detectable clinical deficit. However, if there is degeneration of a sense organ (otolith) which normally has an interrelationship with another sense organ (crista ampullaris), the syndrome of benign paroxysmal positional vertigo may appear. Since similar histopathological changes are found in the contralateral TB of patients with these vestibulopathies [27, 47], antiviral treatment may have a role in the prevention of bilateral symptoms.

The use of this class of antivirals in the management of recurrent vertigo contrasts with the disappointing results observed when they were used to treat other viral insults to the labyrinth. The localization of the pathological lesion (sense organ) in sudden sensorineural hearing loss indicates viral entry via the vascular or cerebrospinal pathway rather than intraneural entry. Therefore, it is likely that the virus has left the labyrinth with the clinical presentation of hearing loss, and the goal is to limit or reverse the pathological lesion using steroids.

Finally, since the efferent neural system to both the auditory and vestibular sense organs travels through the vestibular ganglion [67], associated symptoms may be relieved with antiviral therapy. Tinnitus associated with enhanced otoacoustic emissions due to loss of efferent olivocochlear neural activity [67-69] may be relieved with antiviral therapy. Failure to improve hearing loss or relieve tinnitus is dependent on the degeneration of spiral ganglion cells or the efferent bundle. Symptoms caused by loss of efferent vestibular system function are not known since the function of this component is unknown [70].

\section{References}

- 1 Yardley L, Owen N, Nazareth I: Prevalence and presentation of dizziness in a general practice community sample of working age people. Br J Gen Pract 1998;48:1131-1135.

2 Pennisi E: Going viral: exploring the role of viruses in our bodies. Science 2011;331:1513.

3 Roydhouse N: Vertigo and its treatment. Drug 1974;7:297-309.

- 4 Dix MR, Hallpike CS: The pathology, symptomatology and diagnosis of certain common disorders of the vestibular system. Ann Otol Rhinol Laryngol 1952;61:987-1016.

- 5 Nedzelski J, Barber HO, McImogl L: Diagnosis in a dizziness unit. J Otolaryngol 1986;15:101-104.

- 6 Brandt T. Daroff RB: Physical therapy for benign paroxysmal positional vertigo. Arch Otolaryngol 1980;106: 484-485.

7 Harrison M: Epidemic vertigo - vestibular neuronitis a clinical study. Brain 1962;85:613-670.

- 8 Schuknecht HF, Kitamura K: Vestibular neuritis. Ann Otol Rhinol Laryngol Suppl 1981;90:1-19.

- 9 Nadol JB: Vestibular neuritis. Otolaryngol Head Neck Surg 1995;112:162-172.

10 Hallpike CS, Cairns H: Observations on the pathology of Ménière’s syndrome. J Laryngol Otol 1938;53:624655.

11 Yamakawa, K: Über die pathologische Veranderung bei einen Ménière-Kranken. J Otolaryngol Soc Jpn 1938; 44:2310-2312.

12 Kimura RS, Schuknecht HF: Membranous hydrops in the inner ear of the guinea pig after obliteration of the endolymphatic sac. Pract Otorhinolaryngol 1965;27:343-354.

13 Schuknecht HF, Igarashi M: Pathophysiology of Ménière's Disease. New York, Thieme, 1986, pp 46-54.

-14 Schuknecht H F, Ruby RR: Cupulolithiasis. Adv Otorhinolaryngol, 1973; 20:434-443.

15 Parnes LS: Update on posterior canal occlusion for benign paroxysmal positional vertigo. Otolaryngol Clin North Am 1996;29:333-342. 
Gacek: A Perspective on Recurrent Vertigo

16 Moriarty B, Rutka J, Hawke M: The incidence and distribution of cupular deposits in the labyrinth. Laryngoscope 1992;102:56-59.

17 Bachor E, Wright CG, Karmody CS: The incidence and distribution of cupular deposits in the pediatric vestibular labyrinth. Laryngoscope 2002;112:147-151.

18 Epley JM: The canalith repositioning procedure for treatment of benign paroxysmal positional vertigo. Otolaryngol Head Neck Surg 1992;107:399-404.

19 Bretlau P, Thompson J, Tos M, et al: Placebo effect of surgery for Ménière’s disease: 9-year follow-up. Am J Otol 1989;10:259-261.

20 Blakely BW: A randomized, controlled assessment of the canalith repositioning maneuver. Otolaryngol Head Neck Surg 1994;110:391-396.

-21 Asawavichianginda S, Isiprodil P, Snidvongs K, Supiyaphun: Canalith repositioning for benign paroxysmal positional vertigo: a randomized, controlled trial. Ear Nose Throat J 2000;79:732-734.

22 Gacek RR, Gacek MR: Comparison of labyrinthectomy and vestibular neurectomy in the control of vertigo. Laryngoscope 1996;106:225-230.

23 Gacek, R: Singular neurectomy update. II. Review of 102 cases. Laryngoscope 1991;101:855-862.

24 Karlberg M, Hall K, Quickert N, Hinson J, Halmagyi GM: What inner ear diseases cause benign paroxysmal positional vertigo? Acta Otolaryngol 2000;120;380-385.

25 Hughes CA, Proctor L: Benign paroxysmal positional vertigo. Laryngoscope 1997;107:607-613.

26 Gacek R, Gacek M: The three faces of vestibular ganglionitis. Ann Otol Laryngol 2002;111:103 -114.

27 Gacek R: Ménière's disease is a viral neuropathy. ORL 2009;71:78-86.

28 Gacek R: Pathology of benign paroxysmal positional vertigo revisited. Ann Otol Rhinol Laryngol 2003;112: 574-582.

29 Huygen PLM, Admiraal RJ: Audiovestibular sequelae of congenital cytomegalovirus infection in 3 children representing 3 symptomatically different types of delayed endolymphatic hydrops. Int J Pediatr Otorhinolaryngol 1996;35:143-145.

-30 Wackym PA, Sando I; Molecular and cellular pathology of Ménière's disease. Otolaryngol Clin North Am 1997; 30:947-960.

31 Smith IW, Peutherer JF: The incidence of Herpesvirus hominis antibody in the population. J Hyg (Lond) 1967; 65:395-408.

-32 Meier JL, Straus SE: Comparative biology of latent varicella-zoster virus and herpes simplex virus infections. J Infect Dis 1992;166(suppl 1):S13-S23.

-33 Sadzot-Delvaux C, Baudoux L, Defechereux P, Piette J, Rentier B: Overview of the replication of varicella-zoster virus; in Wolff MH, Shunemann A, Schmidt A (eds): Varicella-Zoster Virus. Molecular Biology, Pathogenesis and Clinical Aspects. Contrib Microbiol. Basel, Karger, 1999, vol 3, pp 21-42.

-34 Roehm PC, Camarena V, Nayak S, Gardner J, Wilson A, Mohr I, Chao MV: Cultured vestibular ganglion neurons demonstrate HSV-I reactivation. Laryngoscope 2011;121:2268-2275.

-35 Vrabec JT: Herpes simplex virus and Ménière’s disease. Laryngoscope 2003;113:1431-1438.

-36 Arbusow V, Strupp M, Wasicky R, Homak E, Schulz P, Brandt T: Detection of herpes simplex virus type 1 in human vestibular nuclei. Neurology 2000;55:880-882.

-37 Arnold W. Niedermeyer HP: Herpes simplex virus antibodies in the perilymph of patients with Ménière's disease. Arch Otolaryngol Head Neck Surg 1997;123:53-56.

-38 Fenton J E, Shinazi A, Turner J, Fagan PA: Atypical vestibular neuritis: a case report. Otolaryngol Head Neck Surg 1995;112:738-741.

39 Davis LE: Viruses and vestibular neuritis: review of human and animal studies. Acta Otolaryngol Suppl 1993; 503:700-773.

40 Schmidt J, Rasmussen AF: Activation of latent herpes simplex encephalitis by chemical means. J Infect Dis 1960;106:154-158.

41 Raubach E, May M, Stroud MH: Vestibular involvement in Bell's palsy. Laryngoscope 1978;85:1396-1398.

$\checkmark 42$ Gacek, RR: On the duality of the facial nerve ganglion. Laryngoscope 1998;108:1077-1086.

-43 Gacek R, Gacek, M: Meatal ganglionitis: clinical pathologic correlation in idiopathic facial paralysis (Bell's palsy). Otorhinolaryngol Nova 1999;9:229-238.

44 Gacek R, Lyon MJ: Evidence of a gustatory-vestibular pathway for protein transport. Otol Neurotol 2010;31: 313-318.

45 Gacek RR: The pathology of facial and vestibular neuronitis. Am J Otolaryngol 1999;20:202-210.

46 Gacek, RR: Evidence for a viral neuropathy in recurrent vertigo. ORL 2008;70:6-15.

47 Gacek R, Gacek MR: Ménière's disease as a manifestation of vestibular ganglionitis. Am J Otolaryngol 2001;22: 241-250.

48 Nadol JB: Positive Hennebert's sign in Ménière's disease. Arch Otolaryngol 1977;103:524-530.

49 Merchant S, Adams JC, Nadol JB: Pathophysiology of Ménière's syndrome: are symptoms caused by endolymphatic hydrops? Otol Neurotol 2005;26:74-81.

50 Wittmaack K: Die entzundlichen Erkrankungsprozesse des Gehororganes; in Wittmaack K (ed): Anatomie und Histologie. Berlin, Springer, 1926, pp 102-379.

-51 Herriott RM: Infectious nucleic acids, a new dimension in virology. Science 1961;134:256-260.

52 Zemanick MC, Strick PL, Dix RD: Direction of transneuronal transport of herpes simplex virus in the primate motor system is strain dependent. Proc Natl Acad Sci USA 1991;88:8048-8051. 
53 Kuypers HG, Ugolini G: Viruses as transneuronal tracers. Trends Neurosci 1990;13:71-75.

54 LaVail JH, Topp KS, Giblin PA, Garner JA: Factors that contribute to the transneural spread of herpes simplex virus. J Neurosci Res 1997;49:485-496.

55 Davis GL: Cytomegalovirus in the inner ear. Case report and electron microscopic study. Ann Otol Rhinol Laryngol 1969;78:1178-1188.

56 Schuknecht HF: Delayed endolymphatic hydrops. Ann Otol Rhinol Laryngol 1978;87:743-748.

57 Akkuzu G, Akkuzu B, Oz Iuoglu LN: Vestibular evoked myogenic potentials in benign positional vertigo and Ménière's disease. Eur Arch Otorhinolaryngol 2006;263:510-517.

-58 Yang WS, Kim SH, Lee JD, Lee W.S: Clinical significance of vestibular evoked myogenic potentials in benign paroxysmal positional vertigo. Otol Neurotol 2008;29:1162-1166.

59 Benson AJ: Interactions between semicircular canals and gravireceptors; in Busby DE (ed): Recent Advances in Aerospace Medicine. Dordrecht, Reidel, 1970, pp 249-261.

60 Benson AJ: Modification of the response to angular accelerations by linear acceleration; in Kornhuber H (ed): Vestibular System. Part II. Applied Aspects. New York, Springer, 1974, pp 281-320.

61 Fluur E, Mellstrom D: Saccular stimulation and oculomotor reactions. Laryngoscope 1970;80:1713-1721.

62 Fluur E: Positional and positioning nystagmus as a result of utriculocupular integration. Acta Otolaryngol 1974;78:19-27.

63 Gacek RR, Rasmussen GL: Fiber analysis of the stato-acoustic nerve of guinea pig, cat and monkey. Anat Rec 1961;139:455-463.

64 Zerhouni EA: US biomedical research: basic translational and clinical sciences. JAMA 2005;294:1332-1348.

65 Westfall JM, Mold J, Fagnan L: Practice-based research - 'blue highways' on the NIH roadmap. JAMA 2007;297: 403-406.

-66 Gacek RR, Schoonmaker JE: Morphologic changes in the vestibular nerves and nuclei following labyrinthectomy in the cat: a case for the neurotrophin hypothesis in vestibular compensation. Acta Otolaryngol 1997;117:244-249.

67 Gacek RR: Efferent innervation of the labyrinth. Am J Otolaryngol 1984;5:206-224.

68 Plinkert PK, Gitter AH, Zenner HP: Tinnitus-associated spontaneous otoacoustic emissions. Acta Otolaryngol 1990;110:342-347.

69 Haginomori S, Makimoto K, Tanaka H, Araki M, Takenaka H: Spontaneous otoacoustic emissions in humans with endolymphatic hydrops. Laryngoscope 2001;111:96-101.

70 Spencer RF, Sismanis A, Kilpatrick JK, Shaia WT: Demyelination of vestibular nerve axons in unilateral Ménière's disease. Ear Nose Throat J 2002;81:785-789. 